\title{
Slow release of data adds to BSE confusion
}

Paris. The focus of European governments' reactions to the 'mad cow' affair shifted from science to politics last week, fanned by a desire to restore consumer confidence in European beef. As it did so, however, their actions came under increasing fire from scientists who claimed that authorities were now over-reacting to data suggesting a possible link between Bovine Spongiform Encephalopathy (BSE) and CreutzfeldtJakob disease (CJD), a fatal neurodegenerative disorder in humans.

Much of this anger has been focused on the British government, and in particular on the fact that details of ten new and unusual cases CJD reported to its independent 13member Spongiform Encephalopathy Advisory Committee (SEAC) were not made speedily available to the scientists responsible for advising other European governments.

Ironically, on the eve of the UK government's announcement two weeks ago, the Edinburgh group that Facing the music: British experts Ray Bradley (left), John investigated the cases was due to pre-

sent an update on the epidemiology of CJD in the United Kingdom at an international conference on spongiform encephalopathies in Paris. But they were recalled by the UK government and did not present the results.

"We are asking ourselves if this was censorship [by the British government]", says Olivier Robain, an expert on human and animal pathology of prions at the Salpêtrière hospital in Paris, who points out that the conference schedule could have been rearranged to allow the Edinburgh team to speak before leaving.

But criticism is no longer restricted to the British actions. At the beginning of this week, many scientists were expressing

\section{France closes risk assessment body}

Paris. In a week that saw worldwide media coverage of the possible risk to humans of 'mad cow' disease, the French government ironically abolished its only independent commission for assessing technological risks, le Collège de la Prévention des Risques Technologiques (CPRT).

The government gave no official explanation of why it decided to abolish the commission, which is attached to the prime minister's office and has produced reports on industries such as nuclear power, biotechnology and chemicals. Indeed, its abolition was announced in a three-line paragraph deep within a decree on the French language.

Rumours of the CPRT's imminent demise had been circulating since the

concern at plans being discussed in Brussels for a widescale culling of British cattle, a move which they claimed could not be justified by the current scientific evidence, but was motivated primarily by public fear.

The repercussions of the way that scientific advice has been handled in the current crisis are likely to reverberate for a long time. For example, one official says that, after the British government went public on the SEAC report, the BSE/CJD research community was "completely paralysed" by

\section{IMAGE UNAVAILABLE FOR COPYRIGHT REASONS}

the lack of the original data. Meetings between French researchers and government officials last week were also hampered by the lack of hard data, according to one French scientist.

"There was a fundamental error of not respecting the rules of scientific communication," says one researcher. Others claim that the public panic could have been reduced if information about the 10 British cases of CJD had been better presented. "Fear feeds on ignorance," says one.

Critics of the way that findings were presented include Philippe Lazar, director general of the French biomedical research agency INSERM. He said in a newspaper

beginning of the year (see Nature $\mathbf{3 7 9}$, $4 ; 1996)$. Its members suspended their work in February in protest at apparent uncertainty over the government's willingness to maintain an "independent institution" with the authority to issue opinions on its own initiative.

Jean-Jacques Salomon, the chairman of CPRT, says that the government's motivation for abolishing the commission cannot be to save money, as it runs on a relatively low budget. He argues that either the government believes that the French "do not face any technological risks", or it does not appreciate criticism, claiming that the abolition was prompted by bodies such as the Atomic Energy Commission which consider the commission "a thorn in the side". D. B. interview that it was unusual for scientific problems of this importance to be handled in the absence of available data, and that it is "unacceptable to trigger reactions of panic" on presumptions that had not yet been demonstrated scientifically, adding: "We have no serious data yet that suggests an epidemic."

Lazar's comments are echoed by German researchers. Hans-Dieter Klenk, a virologist at Marburg University, says that Britain's failure to make the results available have

$\circlearrowleft$ fanned public hysteria. Georg Pauli, head of the department of virology at the Robert Koch Institute, which is responsible for providing advice to the German government on scientific matters, also expresses concern that the data were not released, arguing that this would have allowed more rational discussion, and independent assessment of the danger.

Meanwhile the European Union (EU) has set up a high-level scientific commission to recommend avenues of research into possible links between BSE and CJD, to review existing safeguards and decide whether others are needed. The commission will be chaired by Charles Weissmann, the director of the Institute of Molecular Biology in Zurich, but its composition and detailed remit will not be known until Weissmann meets Franz Fischler, the European commissioner for agriculture, later this week.

Weissmann defends the actions now being taken by European governments to reduce the risk of contamination of humans through British beef products. "Even if the data are not convincing or scientifically conclusive, there is no choice but to act as if they were," he says, adding that it would be "irresponsible not to consider [the new and unusual cases of CJD] as highly suggestive evidence on which one should act".

$\mathrm{He}$ admits that more could have been done previously, arguing that, to his knowledge, no experiments have been done on the feeding of infected material to monkeys, for example. But he warns against recriminations based on the wisdom of hindsight. "We can say that could or should have been done", argues Weissmann. "But if we had taken all the steps we are taking now, people would have said why are you causing billions of pounds of damage by acting on fragmentary or non-existent evidence".

Weissmann says the measures taken by the British government were probably sufficient in the circumstances. The government's error, he says, was to claim that there was no danger of disease passing from cattle to humans, and then to tell farmers, abattoir workers and others that they should be "very careful about how you handle the cattle and the meat".

Declan Butler 